\title{
Implementasi Metode Certanty Factor Pada Sistem Pakar Pendeteksi Kerusakan Printer
}

\author{
Putu Bagus Adidyana Anugrah Putra a,1,* \\ a Jurusan Teknik Informatika, Fakultas Teknik, Universitas Palangka Raya, Kampus UPR Tunjung Nyaho, Palanglangka \\ Raya, Kalimantan Tengah, Indonesia \\ 1 putubagus@it.upr.ac.id* \\ * corresponding author
}

\section{ARTICLE INFO}

\section{Keywords}

Data Flow Diagram

Entity Relationship Diagram

Waterfall

Blackbox

Certainty Factor

\section{ABSTRACT (10PT)}

The printer is an essential requirement in supporting the daily activities of several business fields, namely printing, design, office, and others. Damage to the printer needs proper handling and right so that if not handled immediately will be detrimental to the user. The design of this system uses the Waterfall software development method which consists of five stages, namely requirements definition (feature determination stage), system and software design includes two activities, namely analysis (Data Flow Diagram and Entity Relationship Diagram) (table design, navigation design using a sitemap and interface), implementation and unit testing (realize and test the design results), integration and system testing and operation and maintenance (maintenance). The system was tested with Blackbox testing, which resulted in the system's functionality running well. The calculation process using the Certainty Factor will produce damage experienced and the solution.

\section{Pendahuluan}

Perkembangan teknologi informasi saat ini sudah semakin pesat. Tidak hanya teknologi perangkat keras dan perangkat lunak saja yang mengalami perkembangan pesat, tetapi dalam metode komputasi juga ikut berkembang. Salah satu metode komputasi yang cukup berkembang saat ini adalah metode sistem pengambilan keputusan maupun sistem pakar. Dalam teknologi informasi, sistem pakar merupakan ilmu komputer yang membuat agar mesin dapat melakukan pekerjaan seperti dan sebaik yang dilakukan oleh manusia. Sistem pakar adalah sistem yang menggunakan basis pengetahuan seorang ahli dibidangnya, seperti dokter, teknisi dan lain sebagainya yang dimasukkan ke dalam komputer untuk memecahkan masalah-masalah yang biasanya diselesaikan oleh pakar dengan pendekatan kecerdasan buatan [1][2][3].

Dalam sistem pakar banyak metode yang dapat digunakan, salah satu metode tersebut yaitu Certainty Factor yang akan digunakan dalam penelitian ini. Metode Certainty Factor adalah metode untuk mengakomodasi ketidakpastian pemikiran (inexact reasoning) seorang pakar, selain itu, metode Certainty Factor juga dapat mengambarkan tingkat keyakinan seorang pakar terhadap masalah yang sedang dihadapi [4]. Konsep dari pada metode Certainty Factor yaitu menyatakan kepercayaan dalam sebuah kejadian (fakta atau hipotesis) berdasarkan bukti atau penilaian pakar.

Printer merupakan kebutuhan pokok dalam menunjang aktivitas harian beberapa bidang usaha diantaranya percetakan, desain, kantoran dan lain-lain. Oleh karena itu, kerusakan printer yang sering dialami oleh pengguna sangatlah menghambat kelancaran pekerjaan mereka. Kerusakan-kerusakan tersebut memerlukan penanganan yang tepat dan benar, sehingga jika tidak segera ditangani akan merugikan bagi pengguna.

Proses diagnosa kerusakan printer harus melalui tahapan pemeriksaan secara mendalam dan berurutan. Karena gejala - gejala kerusakan yang muncul sangat aneh dan membingungkan, sehingga suatu jenis kerusakan sulit untuk dibedakan dari kerusakan yang lain. Untuk menangani permasalahan tersebut maka dibutuhkan sebuah sistem yang mampu bekerja otomatis dengan waktu singkat untuk 
menganalisa, menemukan dan memberikan solusi. Dengan mengimplementasikan sebuah sistem pakar.

Dalam penelitian ini data yang digunakan berupa ilmu pengetahuan dan fakta, sehingga sistem pakar merupakan salah satu perangkat lunak yang sesuai untuk pemecahan masalah ini. Karena sistem pakar menyajikan dan menggunakan data yang berbasis pengetahuan. Diharapkan dengan adanya sistem ini dapat membantu para pengguna printer untuk dapat mendiagnosa kemungkinan kerusakan yang terjadi, sehingga dapat mempersingkat waktu untuk proses perbaikannya. Dalam penerapan sistem peneliti menggunakan metode Certainty Factor dimana pada metode ini menggunakan suatu nilai untuk mengasumsi derajat keyakinan seorang pakar terhadap suatu data.

\section{Metodologi Penelitian}

Model yang digunakan merupakan suatu hasil dari siklus hidup pengembangan perangkat lunak Model Waterfall [5] yaitu pada tahap analisis, desain, implementasi dan pengujian. Berikut ini merupakan beberapa tahapan penelitian, yaitu:

1) Studi Pustaka dan Observasi

Metode ini melakukan studi pustaka terhadap buku, jurnal ilmiah nasional dan internasional sebagai pendukung dalam penelitian. Observasi dilakukan untuk mengambil data-data untuk titik dan berapa besar radius yang diperlukan untuk menandakan suatu ruangan yang nantinya akan dijadikan area untuk mengeluarkan informasi.

2) Analisis Sistem

Proses pencarian kebutuhan difokuskan pada software untuk mengetahui sifat dari aplikasi yang akan dibuat, pemodelan proses bisnis menggunakan Data Flow Diagram (DFD) dan Entity Relationship Diagram (ERD).[6] [7]

3) Desain Sistem

Proses ini digunakan untuk membuat blueprint software seperti, perancangan basis data dan perancangan interface.[8][9]

4) Implementasi

Proses ini akan dilakukan pembuatan perangkat lunak sesuai dengan perancangan basis data dan antar muka yang telah dilakukan pada tahap sebelumnya.

5) Pengujian Sistem

Proses pengujian akan dilakukan dengan Blackbox Testing yang disertai dengan melakukan simulasi data. Pengujian BlackBox adalah pengujian aspek fundamental sistem

\section{Hasil dan Pembahasan}

\subsection{Perancangan Sistem}

Perancangan sistem menguraikan bagaimana alur proses input maupun output dari sistem yang akan dihasilkan. Perancangan sistem ini dapat digambarkan melalui diagram aliran data maupun konteks diagram yang akan menggambarkan aliran terhadap sistem yang dirancang.

\subsubsection{Diagram Konteks}

Diagram konteks digunakan untuk menggambarkan kesuluruhan dari sistem yang dirancang. Adapun perancangannya dapat dilihat pada gambar berikut : 


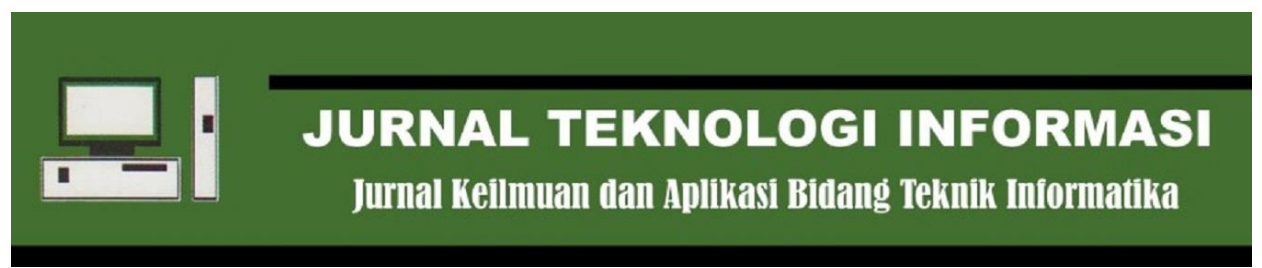

[E-ISSN 2656-0321]

[Vol 14 No 1]

[ Januari 2020]

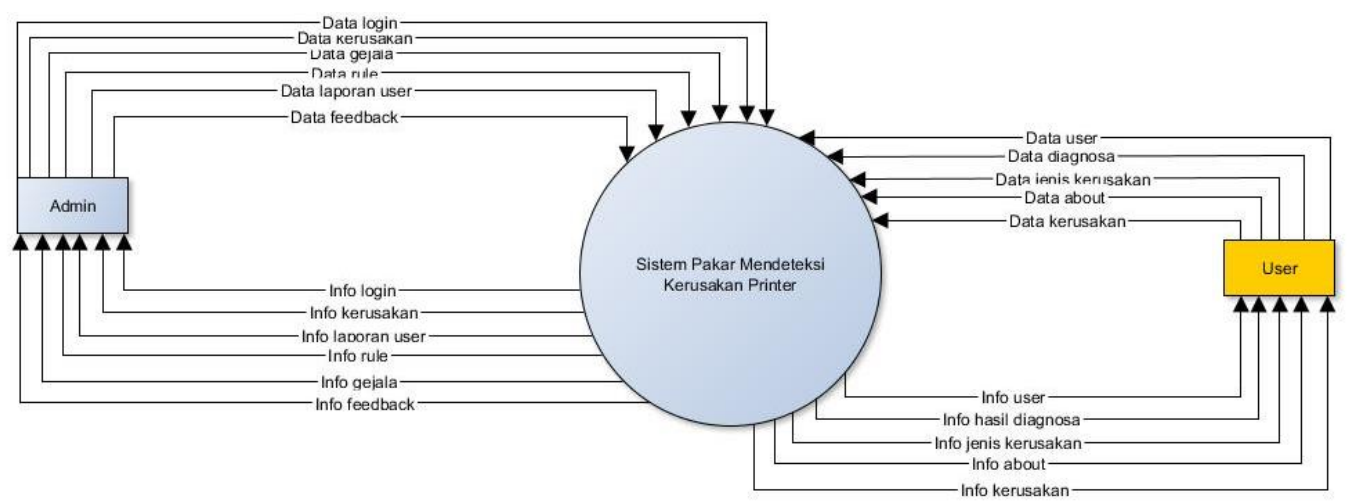

Gambar 3.1 Konteks Diagram

\subsubsection{ERD}

ERD merupakan suatu model untuk mejelaskan hubungan antar data dalam basis data berdasarkan objek-objek dasar data yang mempunyai hubungan antar relasi. ERD untuk memodelkan struktur data dan hubungan antar data, untuk menggambarkannya digunakan beberapa notasi dan symbol yang digunakan. Penekanan utama pada ERD adalah tabel-tabel yang mempresentasikan entitas-entitas serta tabel-tabel yang mempresentasikan relasi (hubungan) antar entitas itu sendiri.

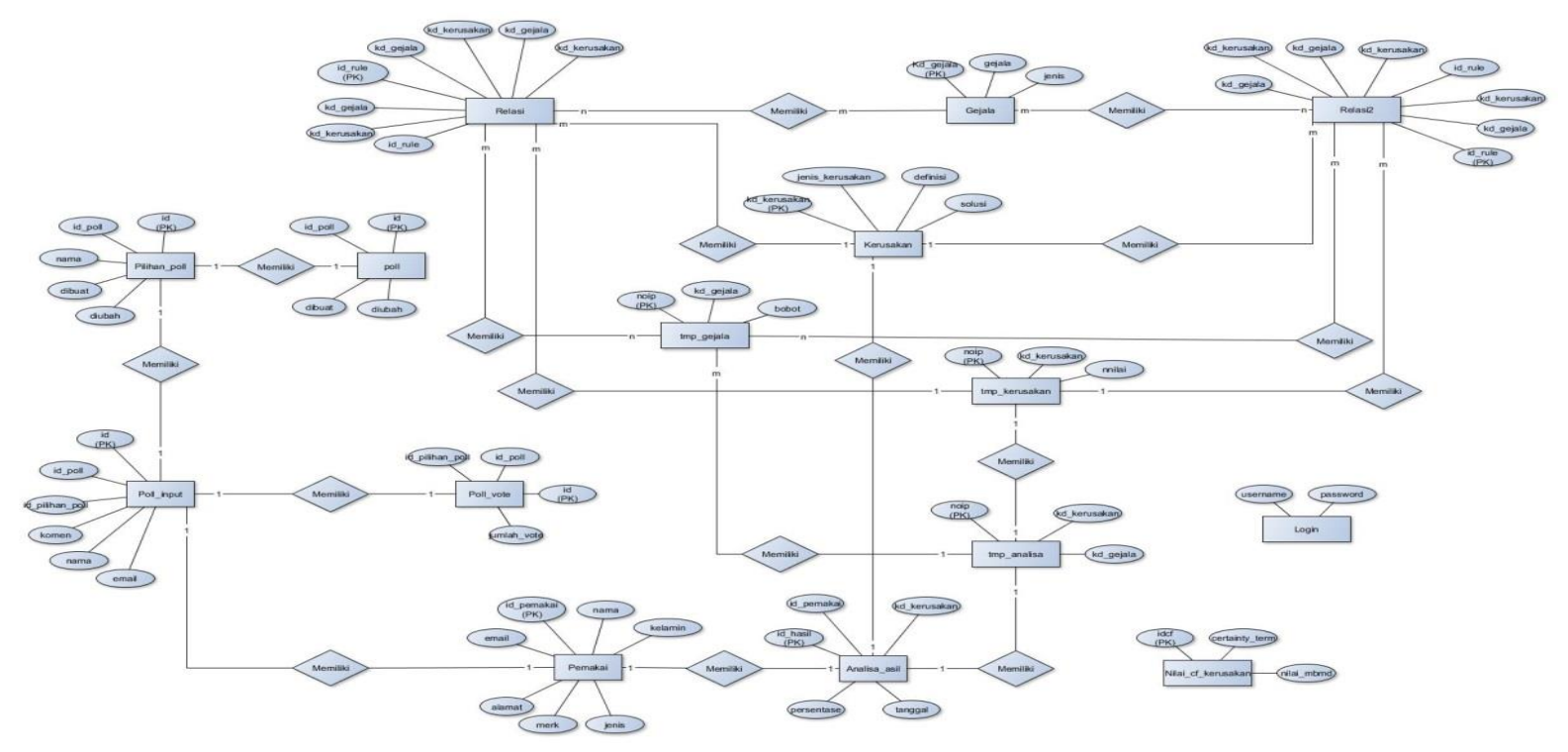

Gambar 3.2 ERD

\subsubsection{Desain Navigasi}

Site Map dalam sistem adalah sebagai berikut :

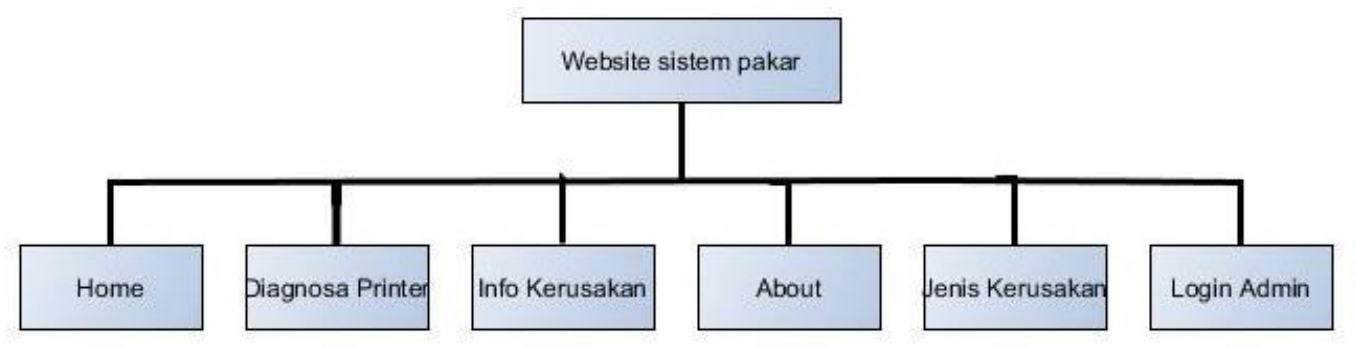

Gambar 3.3 Site Map User 


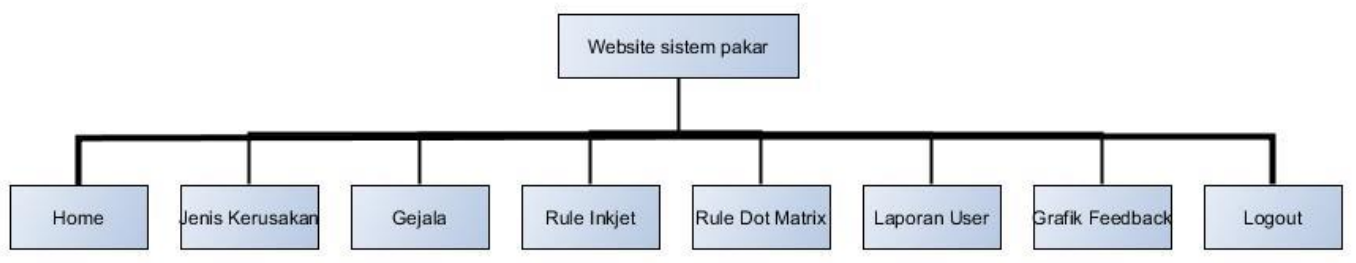

Gambar 3.4 Site Map Admin

\subsection{Implementasi}

\section{1) Halaman Utama}

Halaman utama atau halaman selamat datang merupakan halaman yang pertama tampil ketika pengguna mengakses halaman web. Adapun tampilannya dapat dilihat pada gambar berikut:

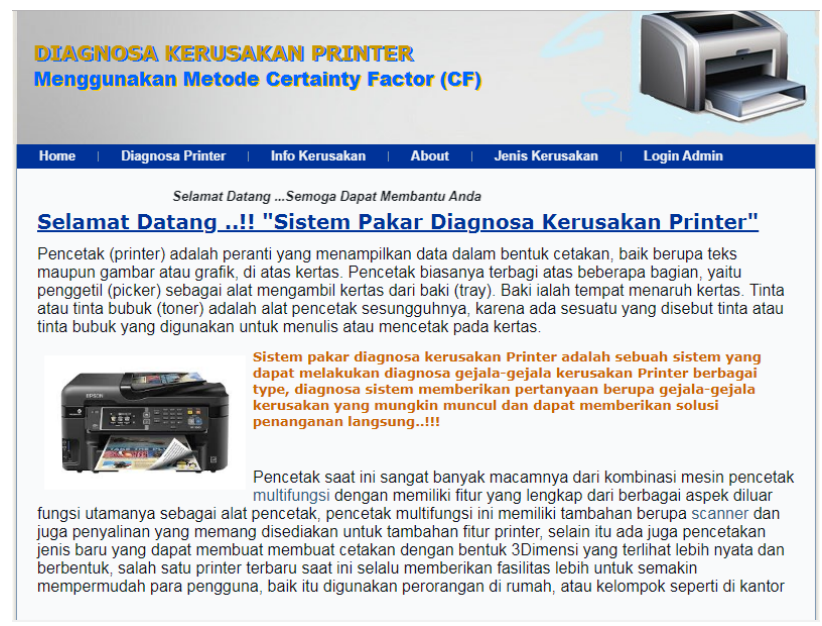

Gambar 3.5 Halaman Utama

2) Halaman Login Admin

Halaman login administrator digunakan untuk melakukan login para administrator untuk masuk ke halaman utama aplikasi. Tampilan halaman login admin dapat dilihat pada gambar berikut :

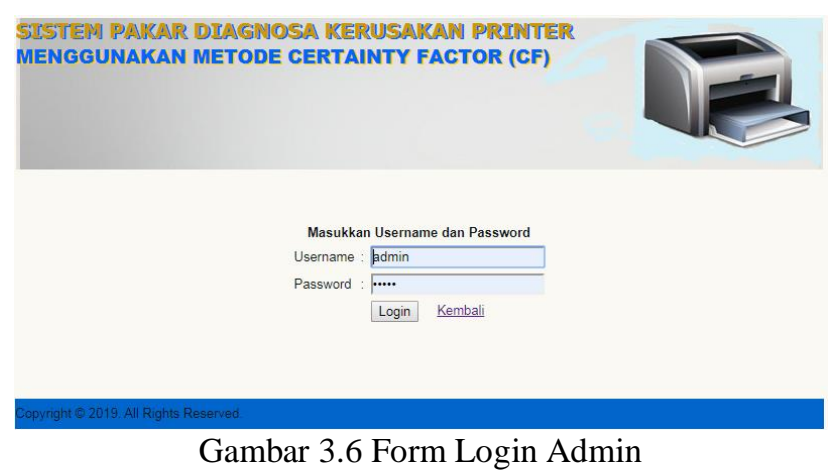

3) Halaman Utama Administrator

Halaman utama administrator merupakan halaman utama pada bagian admin untuk melakukan semua kegiatan dalam sistem. Tampilannya seperti pada gambar berikut : 
Jithe

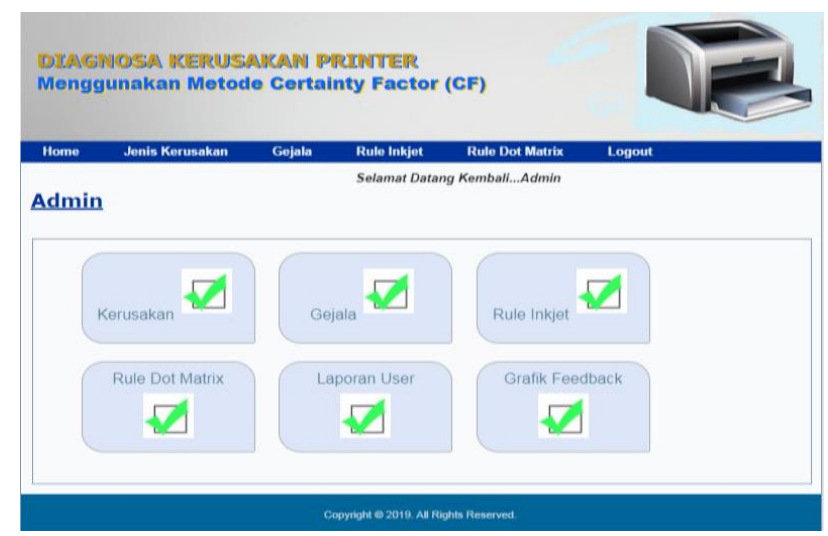

Gambar 3.9 Halaman Utama Administrator

4) Halaman Data Kerusakan

Halaman data kerusakan digunakan untuk menginputkan data kerusakan dan untuk menampilkan kerusakan. Tampilannya seperti pada gambar 4.4 berikut :

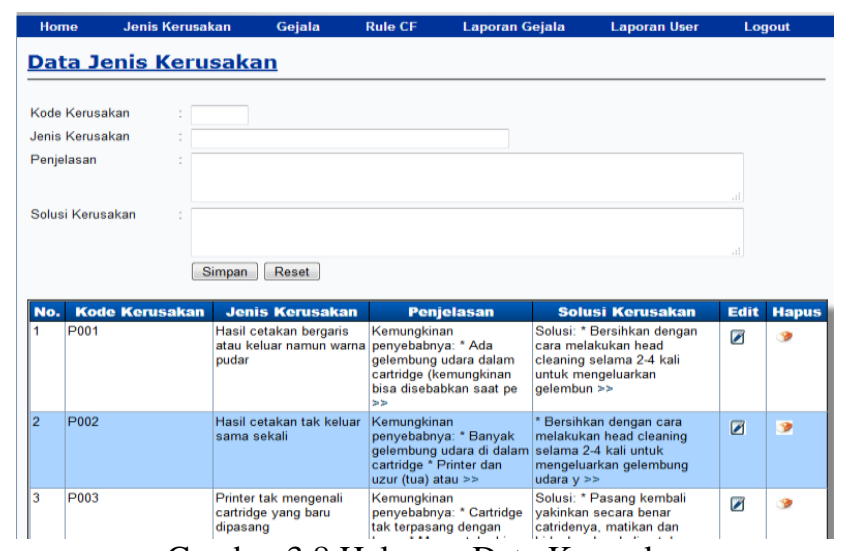

Gambar 3.8 Halaman Data Kerusakan

Fitur tambah keruskan, merupakan fitur untuk menambah data kerusakan pada sistem yang dilakukan oleh admin. Berikut tampilannya, beserta error handling jika tidak mengisi field.

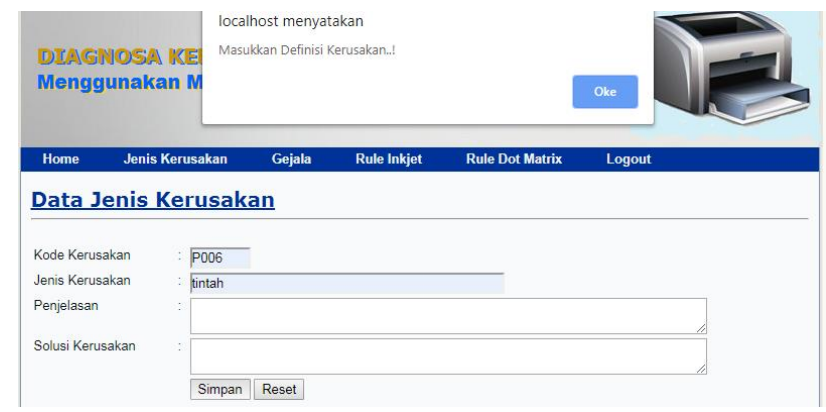

Gambar 3.9 Halaman Tambah Kerusakan

5) Halaman Data Gejala

Halaman data gejala digunakan untuk menginputkan dan menampilkan data gejala. Tampilannya seperti pada gambar berikut : 


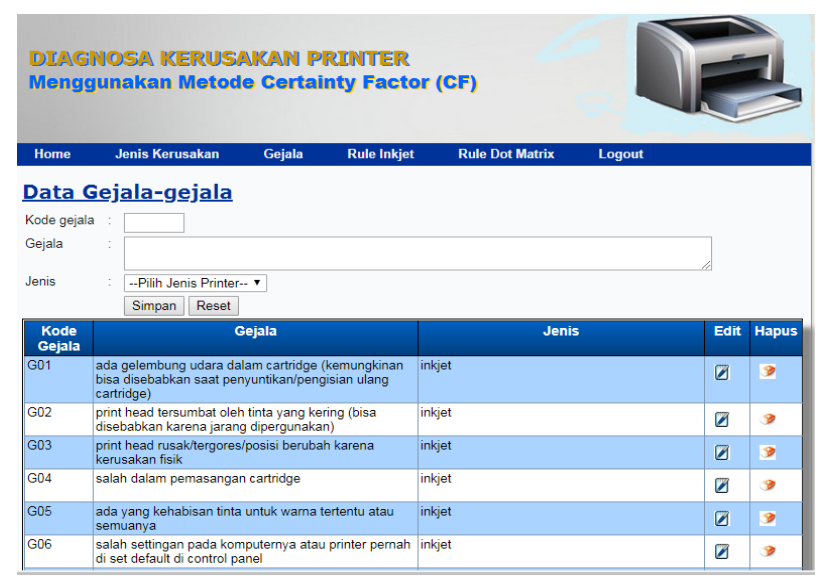

Gambar 3.10 Halaman Data Gejala

6) Halaman Data Rule

Halaman data rule digunakan untuk mengatur rule atau relasi antar kerusakan dan gejala. Dimana terdapat dua rule yaitu inkjet dan dot matrix. Adapun tampilannya dapat dilihat pada gambar berikut :

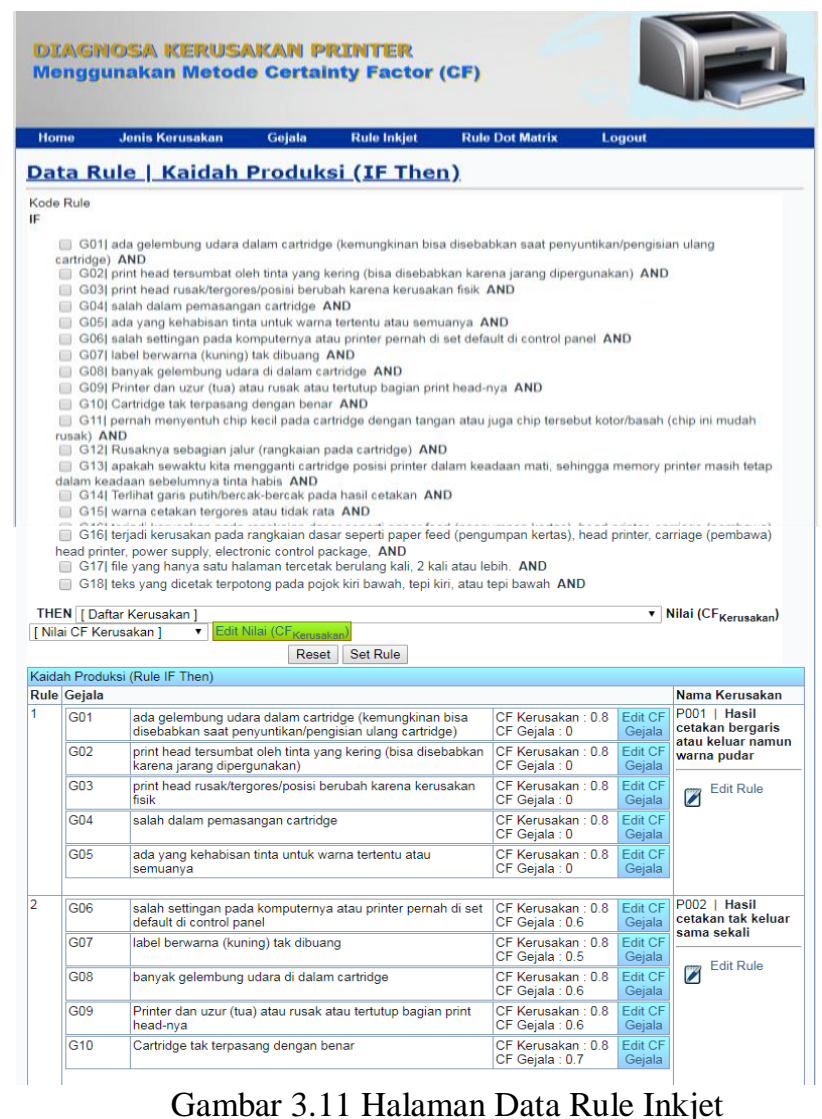

Gambar 3.11 Halaman Data Rule Inkjet 


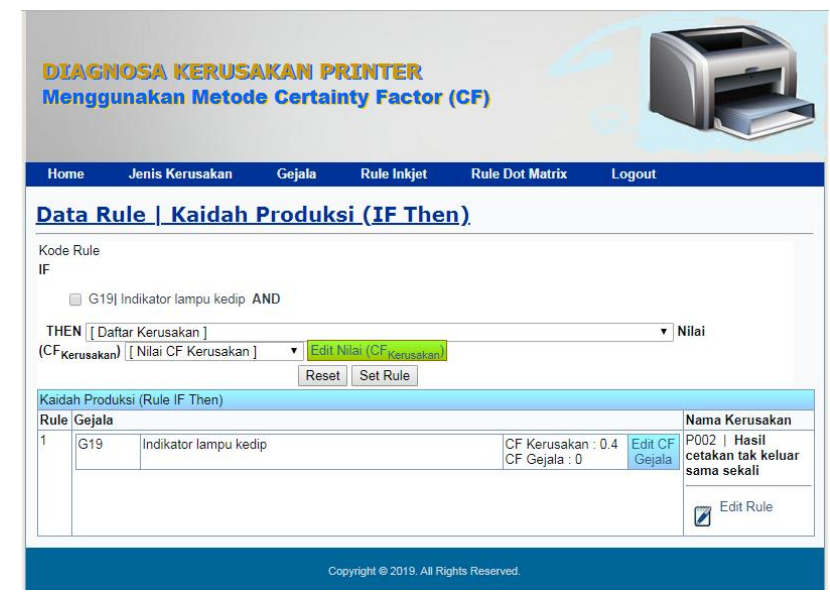

Gambar 3.12 Halaman Data Rule Dot Matrix

Berikut ini merupakan tampilan fitur edit fc gejala, dengan memilih gejala yang ingin diubah nilainya.

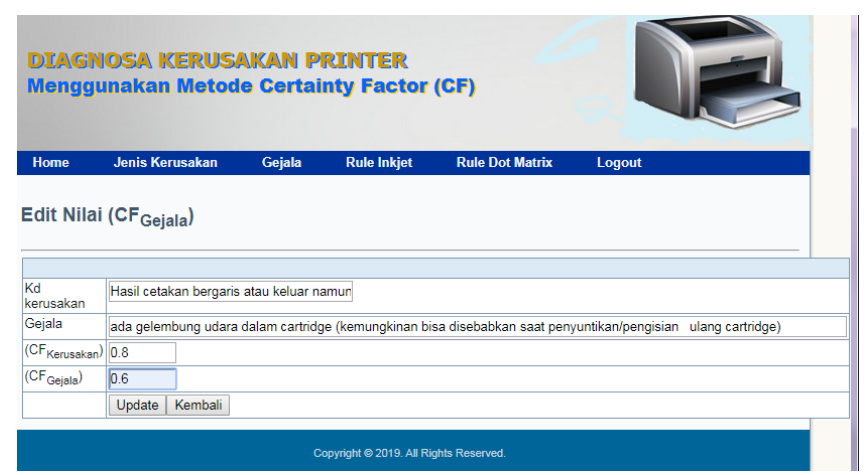

Gambar 3.13 Halaman Edit CF Gejala

Berikut ini merupakan tampilan fitur edit rule dengan mencentang gejala, kemudian memilih jenis kerusakan yang sesuai dengan gejala serta menentukan nilai cf kerusakannya.

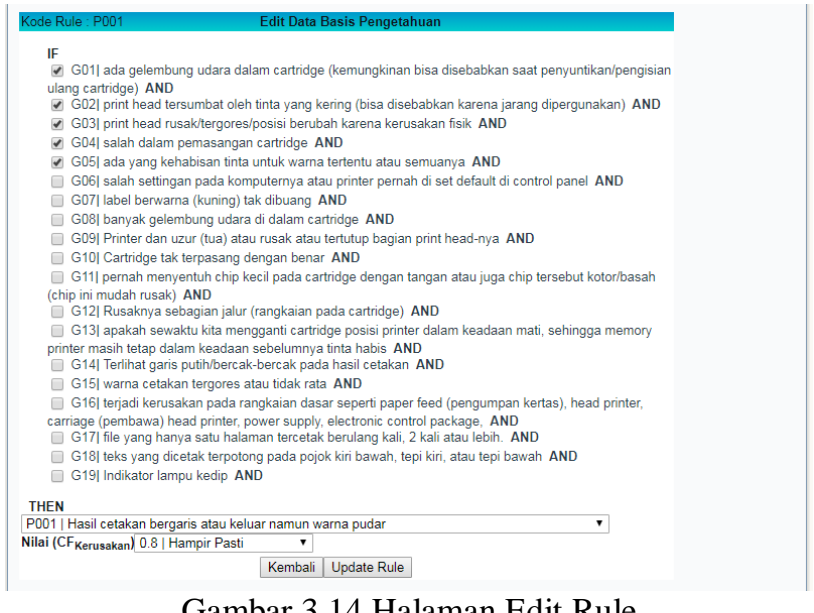

Gambar 3.14 Halaman Edit Rule 
Tabel 3.1 Jenis gejala

\begin{tabular}{cl}
\hline Kode & \multicolumn{1}{c}{ Nama Gejala } \\
\hline G1 & $\begin{array}{l}\text { ada gelembung udara dalam cartridge (kemungkinan bisa disebabkan saat } \\
\text { penyuntikan/pengisian ulang cartridge) }\end{array}$ \\
\hline G2 & $\begin{array}{l}\text { print head tersumbat oleh tinta yang kering (bisa disebabkan karena jarang } \\
\text { dipergunakan) }\end{array}$ \\
\hline G3 & print head rusak/tergores/posisi berubah karena kerusakan fisik \\
\hline G4 & salah dalam pemasangan cartridge \\
\hline G5 & ada yang kehabisan tinta untuk warna tertentu atau semuanya \\
\hline G6 & $\begin{array}{l}\text { salah settingan pada komputernya atau printer pernah di set default di control } \\
\text { panel }\end{array}$ \\
\hline G7 & label berwarna (kuning) tak dibuang \\
\hline G8 & banyak gelembung udara di dalam cartridge \\
\hline G9 & Printer dan uzur (tua) atau rusak atau tertutup bagian print head-nya \\
\hline G10 & Cartridge tak terpasang dengan benar \\
\hline G11 & $\begin{array}{l}\text { menyentuh chip kecil pada catridge dengan tangan atau chip tersebut } \\
\text { kotor/basah }\end{array}$ \\
\hline G12 & rusaknya sebagian jalur (rangkaian pada catridge) \\
\hline G13 & $\begin{array}{l}\text { apakah sewaktu kita mengganti cartridge posisi printer dalam keadaan mati, } \\
\text { sehingga memory printer masih tetap dalam keadaan sebelumnya tinta habis }\end{array}$ \\
\hline G14 & Terlihat garis putih/bercak-bercak pada hasil cetakan \\
\hline G15 & warna cetakan tergores atau tidak rata \\
terjadi kerusakan pada rangkaian dasar seperti paper feed (pengumpan \\
kertas), head printer, carriage (pembawa) head printer, power supply, \\
electronic control package
\end{tabular}

Tabel 3.2 Jenis kerusakan

\begin{tabular}{cl}
\hline Kode & \multicolumn{1}{c}{ Nama Kerusakan } \\
\hline P1 & Hasil cetakan bergaris atau keluar namun warna pudar \\
\hline P2 & Hasil cetakan tak keluar sama sekali \\
\hline P3 & printer tidak mengenali catridge yang baru dipasang \\
\hline P4 & $\begin{array}{l}\text { Setelah dipasang cartridge baru ada peringatan bahwa cartridge yang terpasang } \\
\text { tidak asli }\end{array}$ \\
\hline P5 & Printer tidak dapat mencetak
\end{tabular}


Tabel 3.3 Rule gejala dan kerusakan

\begin{tabular}{|c|c|c|c|c|c|}
\hline Kode & P1 & P2 & P3 & P4 & P5 \\
\hline G1 & $\checkmark$ & & & & \\
\hline G2 & $\checkmark$ & & & & \\
\hline G3 & $\checkmark$ & & & & \\
\hline G4 & $\checkmark$ & & & & \\
\hline G5 & $\checkmark$ & & & & \\
\hline G6 & & $\checkmark$ & & & \\
\hline G7 & & $\checkmark$ & & & \\
\hline G8 & & $\checkmark$ & & & \\
\hline G9 & & $\checkmark$ & & & \\
\hline G10 & & $\checkmark$ & & & \\
\hline G11 & & & $\checkmark$ & & \\
\hline G12 & & & $\checkmark$ & & \\
\hline G13 & & & & $\checkmark$ & \\
\hline G14 & & & & $\checkmark$ & \\
\hline G15 & & & & $\checkmark$ & \\
\hline G16 & & & & $\checkmark$ & \\
\hline G17 & & & & & $\checkmark$ \\
\hline G18 & & & & & $\checkmark$ \\
\hline
\end{tabular}

Dalam perancangan basis pengetahuan ini digunakan kaidah produksi sebagai sarana untuk representasi pengetahuan. Kaidah produksi dituliskan dalam bentuk pernyataan IF (premi) THEN (konklusi). Pada perancangan basis pengetahuan sistem pakar ini premis adalah gejala-gejala pada printer dan konklusi adalah kerusakan pada printer, sehingga bentuk pernyataan adalah IF (gejala) THEN (kerusakan). Bagian premis dalam aturan produksi dapat memiliki lebih dari sau proposisi yaitu berarti dalam satu kaidah dapat memiliki lebih dari satu gejala. Gejala-gejala tersebut dihubungkan dengan menggunakan operator logika AND. Bentuk pernyataannya adalah

IF [Gejala 1]

AND [Gejala 2] AND [Gejala

3]

THEN [Kerusakan]

Adapun contoh beberapa kaidah produksi untuk menentukan kerusakan pada printer adalah sebagai berikut :

\section{Kaidah 1}

IF ada gelembung udara dalam catridge (kemungkinan bisa disebabkan saat penyuntikan/pengisian ulang catridge).

AND print head tersumbat oleh tinta yang kering (bisa disebabkan karena jarang dipergunakan) 
AND print head rusak/tergores/posisi berubah karena kerusakan fisik

AND salah dalam pemasangan catridge

AND ada yang kehabisan tinta untuk warna tertentu atau semuanya

THEN Hasil cetakan bergaris atau keluar namun warna pudar

\section{Kaidah 2}

IF salah settingan pada komputernya atau printer pernah di set default di control panel

AND label berwarna (kuning) tak dibuang )

AND banyak gelembung udara di dalam catridge

AND Printer dan uzur (tua) atau rusak atau tertutup bagian print head-nya

AND Catridge tak terpasang dengan benar

THEN Hasil cetakan tak keluar sama sekali

Kaidah 3

IF menyentuh chip kecil pada catridge dengan tangan atau chip tersebut kotor/basah

AND rusaknya sebagian jalur (rangkaian pada catridge)

THEN printer tidak mengenali catridge yang baru dipasang

\section{Kaidah 4}

IF apakah sewaktu kita mengganti cartridge posisi printer dalam keadaan mati, sehingga memory printer masih tetap dalam keadaan sebelumnya tinta habis

AND Terlihat garis putih/bercak-bercak pada hasil cetakan

AND warna cetakan tergores atau tidak rata

AND terjadi kerusakan pada rangkaian dasar seperti paper feed (pengumpan kertas), head printer, carriage (pembawa) head printer, power supply, electronic control package

THEN Setelah dipasang catridge baru ada peringatan bahwa catridge yang terpasang tidak asli

\section{Kaidah 5}

IF file yang hanya satu halaman tercetak berulang kali, 2 kali atau lebih

AND teks yang dicetak terpotong pada pojok kiri bawah, tepi kiri, atau tepi bawah

THEN Printer tidak dapat mencetak

\subsection{Pengujian}

Pengujian yang dilakukan menggunakan Blackbox Testing, dimana pada pengujian dengan metode ini hanya memfokuskan kepada fungsionalitas dari aplikasi yang dibuat [10]. Pengujian pada Halaman login dilakukan untuk memastikan bahwa halaman login sudah sesuai dengan fungsinya, pada bagian ini admin memasukan username dan password yang tepat untuk dapat masuk pada halaman admin.

Tabel 3.4. Pengujian Login Admin

\begin{tabular}{lllll}
\hline No. & Aksi & Output & Hasil \\
\hline 1. & $\begin{array}{l}\text { Mengisi data login yang salah dan } \\
\text { menekan Enter pada keyboard atau } \\
\text { klik tombol Login }\end{array}$ & $\begin{array}{l}\text { Menampilkan } \\
\text { pemberitahuan dan proses login } \\
\text { gagal karena username dan } \\
\text { password tidak sesuai }\end{array}$ & $\checkmark$ \\
\hline 2. & $\begin{array}{l}\text { Mengisi data login Benar dan } \\
\text { menekan Enter pada keyboard atau } \\
\text { klik tombol Login }\end{array}$ & $\begin{array}{l}\text { Proses login berhasil } \\
\text { Masuk ke Beranda Admin }\end{array}$ & $\checkmark$ \\
\end{tabular}

Pegujian kelola jenis kerusakan dilakukan untuk memasikan apakah semua fitur pada kelola jenis kerusakan sudah sesuai seperti yang diharapkan. Pengujian dilakukan dengan tahap admin melakukan Proses tambah,edit, dan hapus serta fitur lainya. 
Tabel 3.5. Pengujian Kelola Tambah Jenis Kerusakan

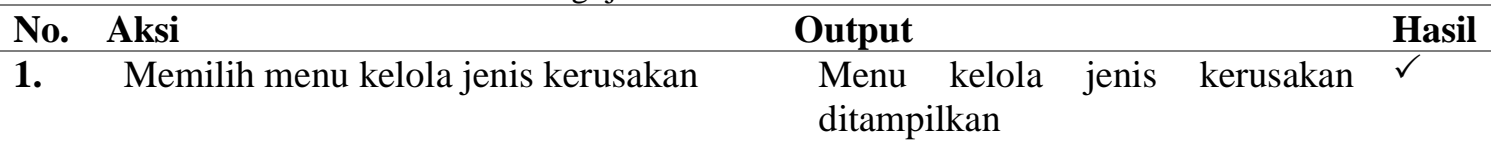

\begin{tabular}{llllll}
\hline 2. & Klik SIMPAN tanpa memasukan nama \\
kode kerusakan atau lainnya & $\begin{array}{l}\text { Muncul pesan bahwa field tidak } \\
\text { boleh kosong maka dat jenis } \\
\text { kerusakan gagal di tambah }\end{array}$ & \\
\hline 3. & $\begin{array}{l}\text { Menambah jenis kerusakan dengan } \\
\text { memasukan data lengkap kerusakan } \\
\text { kemudian tekan SIMPAN }\end{array}$ & $\begin{array}{l}\text { Jenis kerusakan baru berhasil } \\
\text { ditambahkan }\end{array}$ & \\
\hline
\end{tabular}

Tabel 3.7. Pengujian Kelola Edit Jenis Kerusakan

\begin{tabular}{llll}
\hline No. & Aksi & Output & Hasil \\
\hline 1. & Memilih menu kelola jenis kerusakan & $\begin{array}{l}\text { Menu kelola jenis kerusakan } \\
\text { ditampilkan }\end{array}$ & $\checkmark$ \\
\hline 2. & $\begin{array}{l}\text { Pilih jenis kerusakan yang akan diubah } \\
\text { kemudian pilih Aksi Ubah }\end{array}$ & $\begin{array}{l}\text { Menampilkan menu edit } \\
\text { jenis kerusakan yang dipilih }\end{array}$ & $\checkmark$ \\
\hline 3. & $\begin{array}{l}\text { Hapus salah satu isi pada kolom ubah } \\
\text { jenis kerusakan kemudian pilih SIMPAN }\end{array}$ & $\begin{array}{l}\text { Menampilkan pesan bahwa } \\
\text { kolom tidak Boleh kosong }\end{array}$ & $\checkmark$ \\
\hline 4. & $\begin{array}{l}\text { Ubah nama jenis kerusakan dengan nama } \\
\text { lain kemudian pilih SIMPAN }\end{array}$ & $\begin{array}{l}\text { Proses edit jenis kerusakan } \\
\text { berhasil }\end{array}$ & $\checkmark$ \\
\hline
\end{tabular}

\section{Kesimpulan}

Dalam merancang sistem ini digunakan metode pengembangan perangkat lunak Waterfall yang terdiri atas lims tahapan, yaitu requirements definition, system and software design, implementation and unit testing, integration and system testing dan operation and maintenance. Pada tahap pengujian sistem menggunakan blackbox testing dengan hasil pengujian fungsionalitas sitem sudah berjalan sesuai dengan yang diinginkan.

\section{Daftar Pustaka}

[1] S. Sam'ani, and M. H. Qamaruzzaman, "Sistem Pakar Pendeteksi Kerusakan Notebook Menggunakan Metode Certainty Factor” Journal Speed - Sentra Penelitian Engineering dan Edukasi - Volume 10 No 1 2018

[2] A. M. H. Pardede, and B. S. Ginting, "Perancangan Sistem Pakar Deteksi Kerusakan Printer Canon berbasis web”, Jurnal KAPUTAMA, Vol.7 No.1, Juli 2013: 36-43.

[3] A. Saputra, and H. A. Taman, "Sistem Pakar Kerusakan Mesin Jahit dengan Metode Certainty Factor Berbasis Android", Journal of Applied Intelligent System, Vol.1, No. 1, Februari 2016: 36-47.

[4] T. Sutojo, E. Mulyanto, V. Suhartono, "KecerdasanBuatan”, Andi Yogyakarta, Semarang, 2010

[5] Pressman, S. Roger. 2010. Pendekatan Praktisi Rekayasa. Perangkat Lunak. Edisi 7. Penerbit Andi. Yogyakarta. Halaman $45-.46$

[6] Putra, P. B. A. A., Sari, N. N. K dan Pranatawijaya, V. H. 2017. Analisis Dan Desain Website Monitoring Konsultasi Bimbingan Kartu Rencana Studi (KRS). Jurnal Teknologi Informasi. Volume 11, Nomor 1, Januari 2017 
[7] Pranatawijaya, V. H., Putra, P. B. A. A dan Gunawan, V. A. 2016. Pengembangan Perangkat Lunak Generate File Untuk Migrasi Data EPSBEDKe Format Table Feeder PDDIKTI.Jurnal Saintekom, Vol 6, No. 2, September 2016

[8] Pranatawijaya, V. H., Putra, P. B. A. A.,Widiatry, W dan Sari, N. N. K. 2018. Pengembangan Perangkat Lunak Generate File Akun Uang Kuliah Tunggal (UKT) Universitas Palangka Raya.Jurnal Saintekom, Vol 6, No. 2, September 2018

[9] Putra, P. B. A. A., Pranatawijaya, V. H., Widiatry, W., Lisa. 2017. Rancang Bangun Sistem Informasi Pencarian Data Mahasiswa Dan Dosen Pada Fakultas Hukum Universitas Palangka Raya. Jurnal Teknologi Informasi. Volume 11, Nomor 2, Agustus 2017

[10]Harsh, B., Khanna, E dan Sudha. 2014. Black Box Testing based on Requirement Analysis and Design Specifications. International Journal of Computer Applications (0975-8887). Volume 87No.18, (February) 